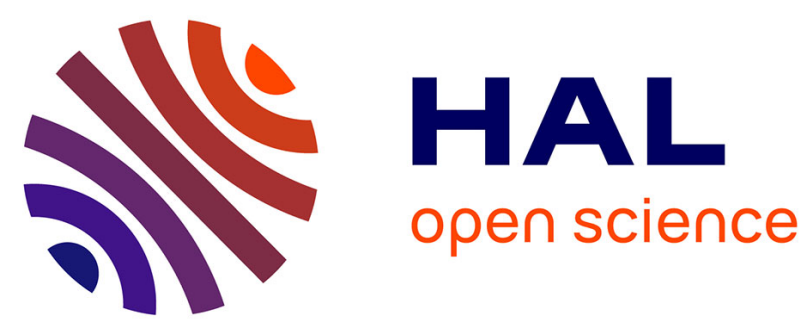

\title{
INTERFACES IN SiC FIBER-REINFORCED GLASS-CERAMIC COMPOSITES
}

L. Mazerolles, D. Michel, L. Ulmer, J. Pastol, M. Parlier, M. Ritti

\section{To cite this version:}

L. Mazerolles, D. Michel, L. Ulmer, J. Pastol, M. Parlier, et al.. INTERFACES IN SiC FIBERREINFORCED GLASS-CERAMIC COMPOSITES. Journal de Physique Colloques, 1990, 51 (C1), pp.C1-879-C1-883. 10.1051/jphyscol:19901138 . jpa-00230049

\section{HAL Id: jpa-00230049 https://hal.science/jpa-00230049}

Submitted on 1 Jan 1990

HAL is a multi-disciplinary open access archive for the deposit and dissemination of scientific research documents, whether they are published or not. The documents may come from teaching and research institutions in France or abroad, or from public or private research centers.
L'archive ouverte pluridisciplinaire HAL, est destinée au dépôt et à la diffusion de documents scientifiques de niveau recherche, publiés ou non, émanant des établissements d'enseignement et de recherche français ou étrangers, des laboratoires publics ou privés. 
INTERFACES IN SIC FIBER-REINFORCED GLASS-CERAMIC COMPOSITES

\author{
L. MAZERolles, D. MIChEL, L. UlMER, J.L. PASTol, M. PARLIER* and \\ M.H. RITTI* \\ CNRS-URA 302, 15 Rue Georges Urbain, F-94400 Vitry, France \\ om, ONERA, 29 Avenue de la Division Leclerc, F-92322 Chatilion, France
}

\begin{abstract}
Résumé - Les interfaces entre des fibres de SiC Nicalon et une matrice vitrocéramique LAS (lithium aluminum silicate) ont été étudiées par microscopie électronique en transmission associée à une analyse locale par dispersion d'énergie $X$. La mise en évidence de carbure de nlobium à l'interface permet d'expliquer les différences de propriétés mécaniques observées suivant les êléments mineurs ajoutés dans la matrice.
\end{abstract}

Abstract - Interfaces between SiC Nicalon fibers and a lithium aluminum silicate (LAS) glass-ceramic matrix were investigated by transmission electron microscopy and energy-dispersive $X$-ray spectroscopy (EDS). Minor additive elements in the matrix, like niobium, can modify the mechanical properties of the composite because of the formation of niobium carbide at the fiber-matrix interface.

\title{
1 - INTRODUCTION
}

Ceramic-ceramic composites have interesting applications due to their high strength and fracture toughness. In particular, materials consisting of a glass-ceramic matrix reinforced by SiC Nicalon fibers have been prepared and investigated by various authors (1-6). The bonding between fibers and matrix at interfaces is a critical parameter in controlling the fracture behavior of the composite. We report here results of an electron microscopy study of interfaces in two types of SiC-LAS composites.

\section{2 - EXPERIMENTAL METHODS}

The crystalline phases present in the composites are revealed from X-ray diffraction powder diagrams. The microstructures are studied on a ZEISS DSM950 scanning electron microscope. TEM observations are achieved using a JEOL 200OFX on transverse sections of unidirectional composites thinned by argon ion milling. Each microscope is equipped with a TRACOR energy-dispersive X-ray spectrometer using a Sili detector with a beryllium window. The analyses are limited to elements with $Z>10$. Therefore. we cannot detect carbon, oxygen and lithium contained in the composites, but the quantitative analysis of the other elements (aluminum, silicon, magnesium, niobium and zirconium) has been achieved. The spatial resolution in SEM is about $1 \mu \mathrm{m}$ and a spot of about $20 \mathrm{~nm}$ can be selected for analysis in TEM at $200 \mathrm{KV}$. 


\section{3 - RESULTS AND DISCUSSION}

Experiments are carried out on two unidirectional composites prepared by a s route and containing a same volume fraction of SiC Nicalon fibers. The starting $\varepsilon$ (LAS $\mathrm{n}^{\circ} 727 \mathrm{I}$ for composite I and LAS $\mathrm{n}^{\circ} 6861$ for composite II) have the composition in major constituents (aluminum, lithium and sllicon), but the nu additive in $\mathrm{n}^{\circ} 7271$ is only nlobium pentoxide whereas $\mathrm{n}^{\circ} 6861$ contains zirconium and nioblum oxide. Previous measurements of mechanical propertie: shown that these additions significantly influence the fracture behavior composites (7).

$\mathrm{XRD}$ analyses indicate that the main crystalline constituent is a $\beta$-spodumene ph both cases. Careful examination of the spectra of composite I allows to detect add very weak lines corresponding to $d$ spacings of a cubic face centered lattici parameter $a=0.4455 \mathrm{~nm}$. This value corresponds to that of a $\mathrm{NbC}_{1-\mathrm{x}}$ phase.

Chemical analyses in SEM indicate a higher content in nioblum around SiC fib composite I. This is fllustrated on Figure 1 by the X-ray mapping of nioblum as $v$ those of the major elements silicon and aluminum.

The TEM study confirms the occurrence of niobium carbide at the matris interface of composite 1 and not in the other composite. Figure 2 shows fiber-1 debonding in composite $I$ and the presence of a coronary zone with a thickness $100 \mathrm{~nm}$ around a SiC fiber. This intermediate zone is not observed in compo (Figure 3). Observations of the interface in composite $I$ at higher magnification crystals which are oriented perpendicularly to the fiber. Diffraction patterns can indexed with the previously mentioned $\mathrm{cfc} \mathrm{NbC}_{1-\mathrm{x}}$ unit-cell and crystals are elor along a [001] growth direction (Figure 4). The selective analysis of the larger crys possible using a small electron probe, it indicates that nlobium is the only el detected except traces of silicon which likely comes from the surrounding LAS I glass (Figure 5).

In conclusion, the formation of niobium carbide in composite I results fro interface reaction between carbon coming from the fiber and niobium oxide cont in the LAS matrix. The different behavior of composite 11 can be explained $k$ observation of precipitates of a mixed zirconlum-nioblum oxdde compound in the ceramic matrix.

\section{REFERENCES}

/1/ PREWO, K. M., and BRENNAN,J.J., J. Mater. Scl., 15 (1980) 463

12/ PREWO, K. M., BRENNAN,J.J., and LAYDEN, G.K., Ceram. Bull., 65 (1986) 305

/3/ CHAIM, R., and HEUER, A. H., Adv. Ceram. Mater., 2 (1987) 154

/4/ COOPER, R.F., and CHYUNG, K., J. Mater. Sci., 22 (1987) 3148

/5/ VIGNESOULT, S., PARLIER., M., and RITTI, M-H., to be published

/6/ BISCHOFF, E., RUHLE, M., SBAIZERO, O., and EVANS, A.G., J. Am. Ceram. So (1989) 741

/7/ PERES, P., FR ISSN 0078-3781 ONERA Technical Note 1988-4. 


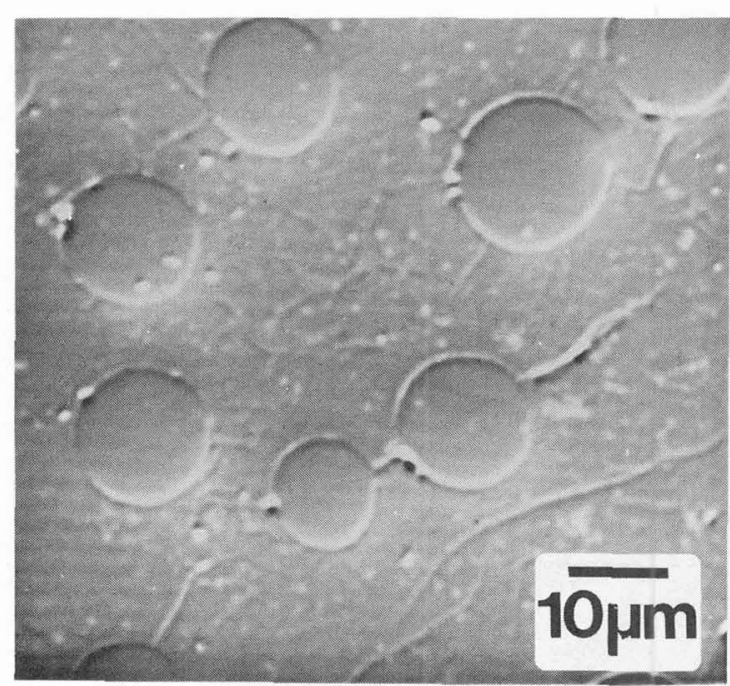

Secondary electron image

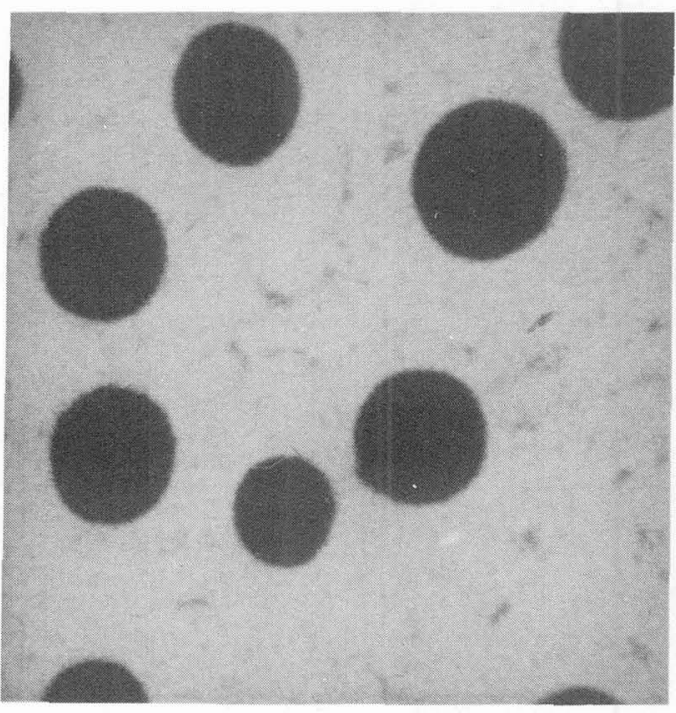

$\mathrm{X}$-ray image of aluminum

$\left(\mathrm{K}_{\alpha}\right.$ line)

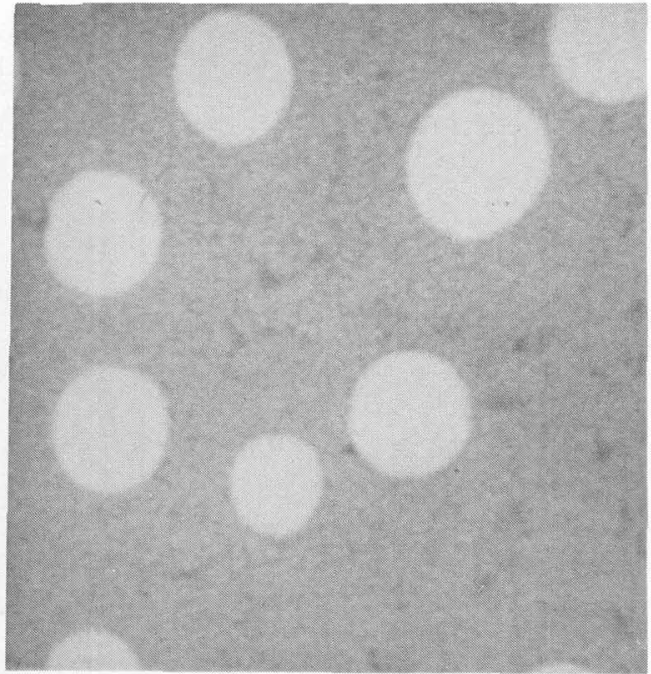

$\mathrm{X}$-ray image of silicon

( $\mathrm{K}_{\alpha}$ line)

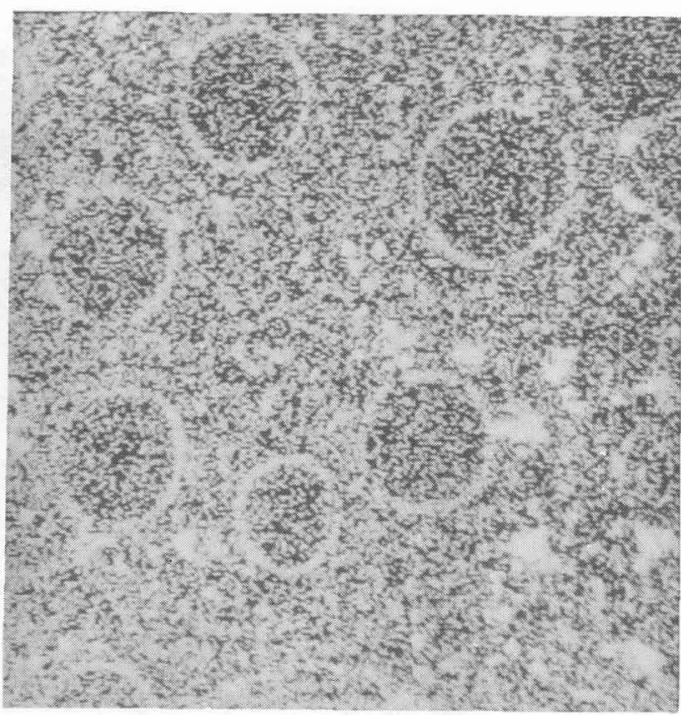

$\mathrm{X}$-ray image of niobium

$\left(\mathrm{L}_{\alpha}\right.$ line)

Fig. 1 : X-ray mapping in SEM of the transverse section of composite I. 


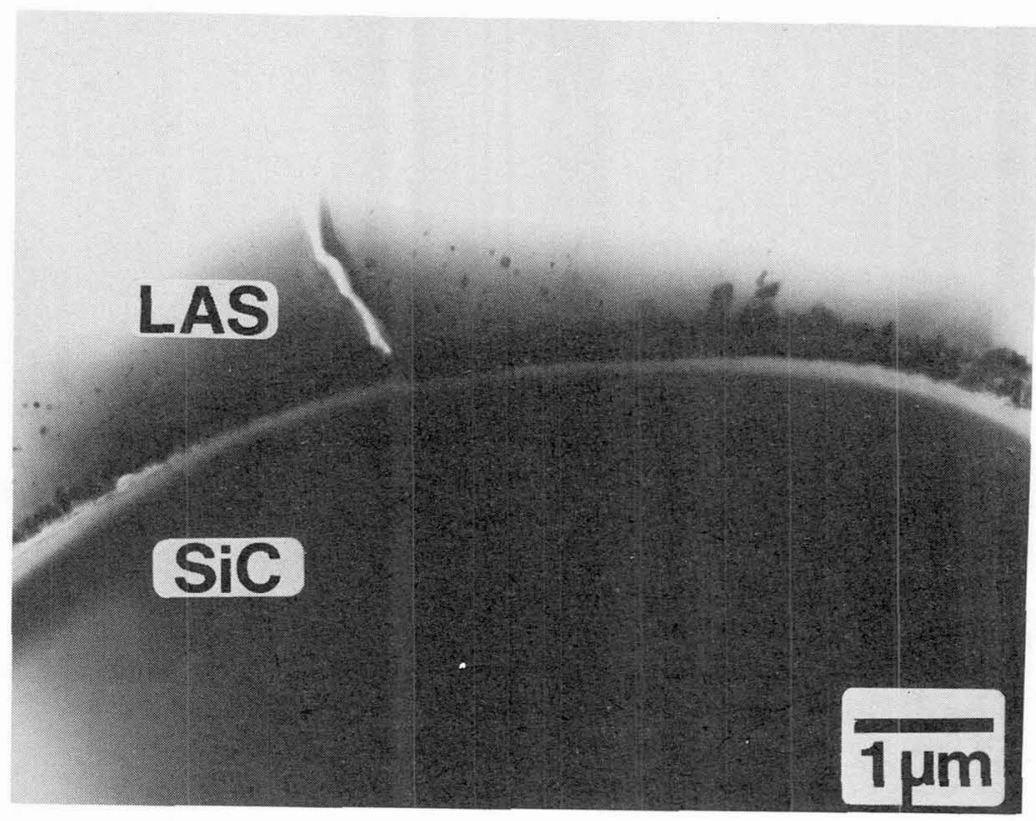

Fig. 2 : TEM image of the fiber-matrix interface in composite I.

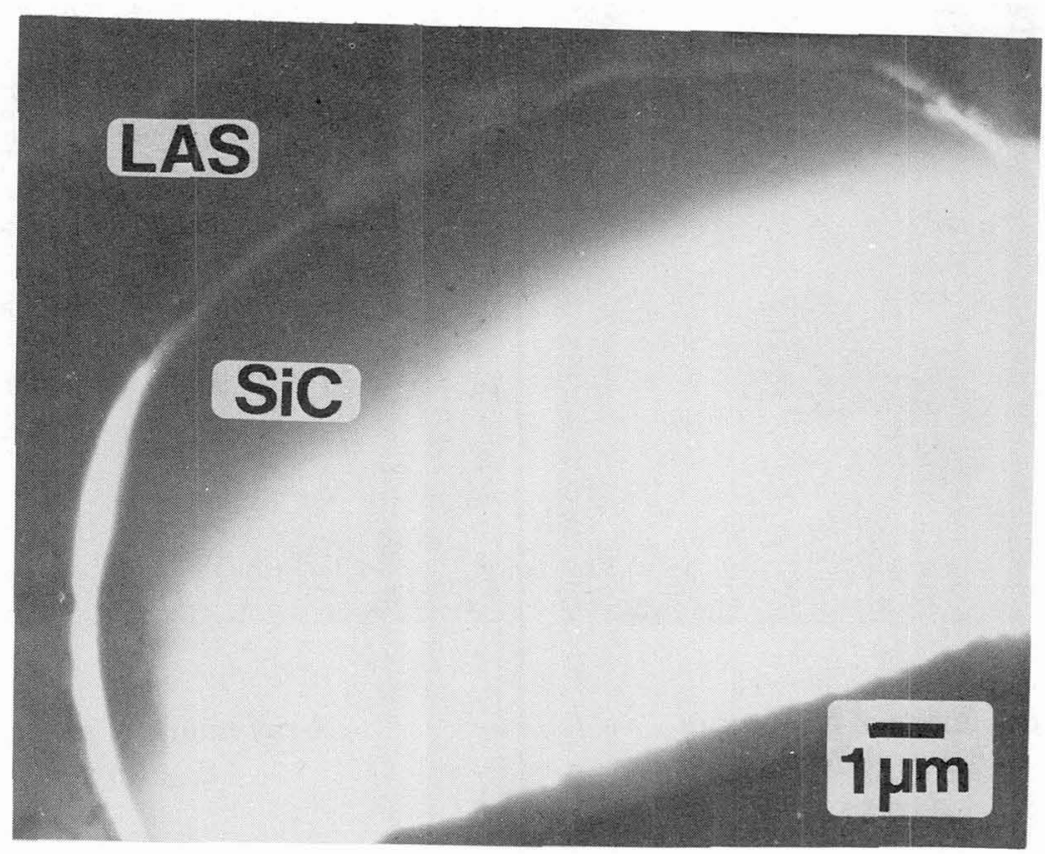

Fig. 3 : TEM image of the fiber-matrix interface in composite II. 

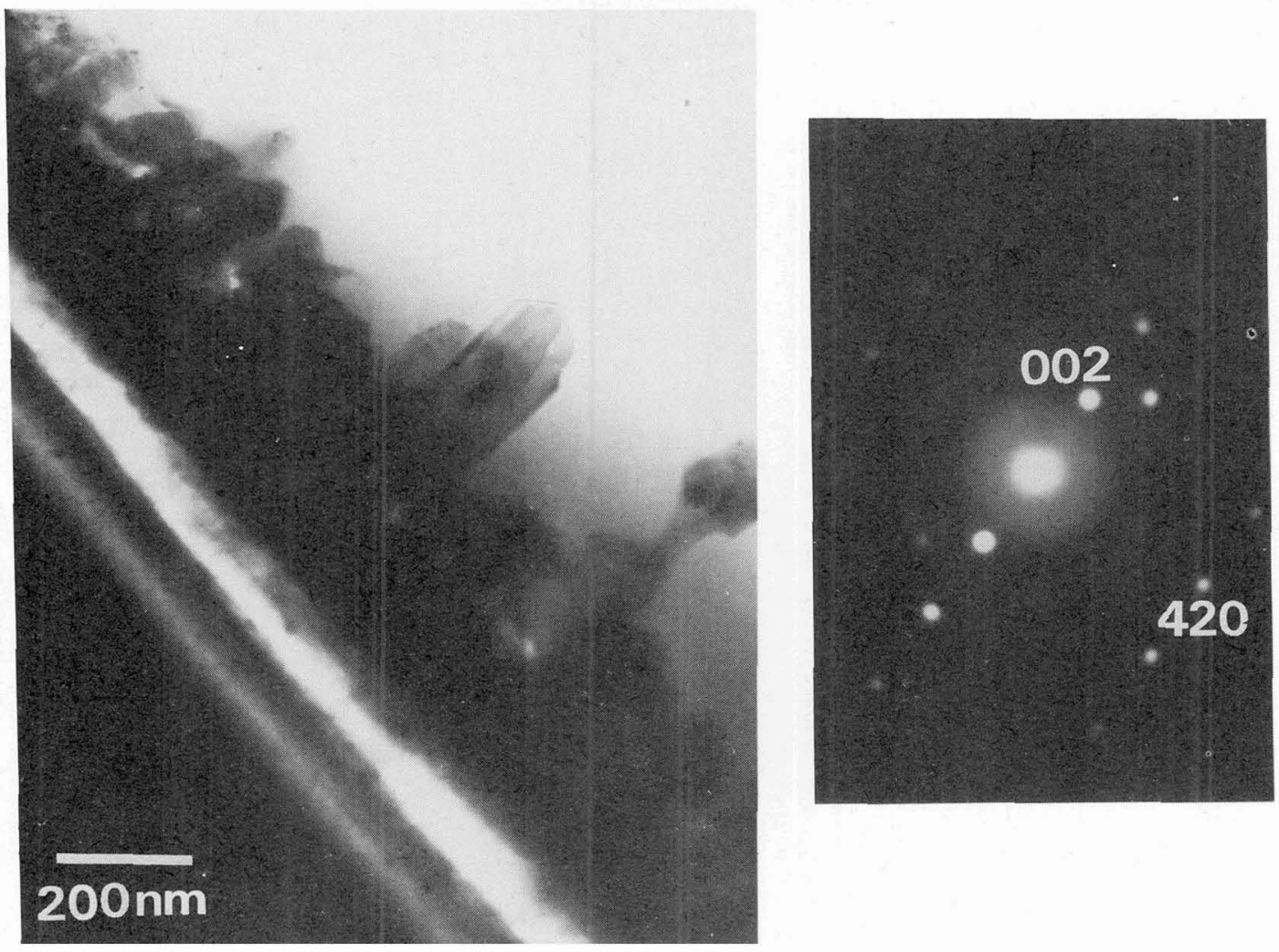

Fig. 4 : TEM image of the fiber-matrix interface (composite I). The electron diffraction pattern corresponds to the largest niobium carbide crystal.

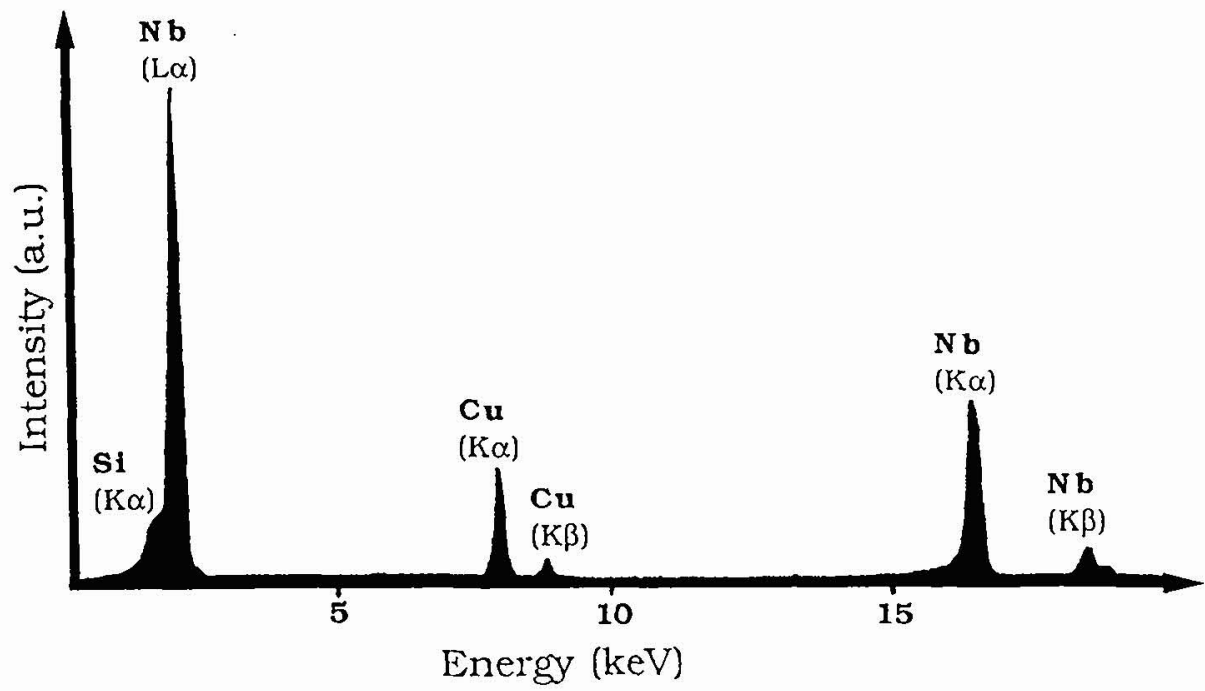

Figure 5 : Dispersive energy X-ray spectrum of the largest crystal on Figure 4. Lines relative to copper come from the specimen-holder grid. 